\title{
COMPARATIVE ANALYSIS OF RUBBER SEED METHYL ESTER WITH OTHER METHYL ESTERS
}

\section{S. EZEANYANASO, E. M. OKONKWO, E. B. AGBAJI, S. GADIMOH, K. O. NWANYA AND O. J. OKUNOLA}

(Received 11, September 2009; Revision Accepted 22, February 2010)

\begin{abstract}
This study was carried out to compare the physico-chemical properties of rubber seed methyl ester with other methyl esters of non-edible oil. In order to achieve a two-step transesterification process was developed to convert rubber seed oil to its methyl esters. The first step, acid catalyzed esterification reduces the (free fatty acid) FFA content of the oil to $\sim 1 \%$. The second step, alkaline catalyzed transesterification process converts the products of the first step to its mono-esters and glycerol. The free fatty acid composition and the important properties of rubber seed oil with other oils determined. The important properties of biodiesel such as specific gravity, flash point, cloud point and pour point were determined and compared with that of diesel. Other properties such as kinematic viscosity sulphur content, Aniline point and Acid value of rubber seed methyl ester were deduced and compared with other methyl esters. From the results obtained, the transesterification process was found to improve the fuel properties of the oil with respect to specific gravity, viscosity, flash point and acid value. The comparison of these properties with diesel shows that the methyl ester from rubber seed oil has a relatively close fuel propety values to that of diesel, making it a viable alternative to the diesel fuel.
\end{abstract}

KEYWORDS: Rubber seed oil, methyl Ester, Transesterification, Comparative

\section{INTRODUCTION}

The need for energy is increasing continuously, because of increase in industrialization and population. The basic sources of this energy are petroleum, natural gas, coal, hydro, and nuclear waste. In the recent years, systematic efforts have been made by several researchers (John and Mark, 1996; Canakei and Van Gerpan, 1999; Agarwal and Das, 2001; Recep et al., 2001; Pilar et al., 2004; Erhan and Sharma, 2006) to use various vegetable oils as fuel in compression ignition engines. Vegetable oils are becoming a promising alternative to diesel fuel because they are renewable in nature and can be produced locally and environmental friendly as well. Currently, most of the biodiesel is produced from refined/edible type oils using methanol and alkaline catalyst. However, large amount of nonedible type oils and fats are available. The difficulty with alkaline esterification of these oils is that they contain large amounts of free fatty acids (FFA) (John and Mark, 1996).

These free fatty acids quickly react with the alkaline catalyst to produce soaps that inhibit the separation of the ester and glycerin Diesel fuels produced from vegetable oils have practically no sulphur content, no green house emissions especially with $\mathrm{CO}_{2}$, offer no storage difficulty, and they have excellent lubrication properties. Moreover, vegetable oils yielding trees absorb more carbon dioxide from the atmosphere on burning (Erhan and Sharma, 2006). Hence, they essentially help to alleviate the increasing carbon dioxide content in the atmosphere. The substitution of diesel oil by renewable fuels produced within the country generates higher foreign exchange savings, even for the major oil exporting countries e.g. Nigeria. Therefore developing countries can use this kind of project not only to solve their economical problems but also to improve their economy. In view of the several advantages, vegetable oil has potential to replace petroleum-based fuels in long run.

Rubber seed plant which is widely used as a natural source of rubber has been reported to have oil rich seeds which are non-edible. Although there are variations in the oil content of the seed from different countries, the average oil field have been reported to be $40-50 \%$ of brown color oil. The estimated annual rubber seed production potential in Nigeria is $42,980 \mathrm{mt}$ (Ramadhas et al., 2004) and 13,929mt of rubber seed oil could be obtained. Availability of rubber seed in Nigeria especially in Southern part of the country is over $30,000 \mathrm{mt}$ per year which can yield rubber seed oil (RSO) to the tune of over $10,000 \mathrm{mt}$. Rubber trees yield 3-seeded elliposoidal capsule, each carpel with one seed. Rubber seeds are variable in size, $3.5 \mathrm{~cm}$ long, mottled brown, lustrous, weighing $3-4 \mathrm{~g}$ each. The capsules are spread over the ground and are usually

C. S. Ezeanyanaso, National Research Institute for Chemical Technology, P.M.B. 1052, Zaria Nigeria.

E. M. Okonkwo, National Research Institute for Chemical Technology, P.M.B. 1052, Zaria Nigeria.

E. B. Agbaji , Department of Chemistry Ahmadu Bello University Zaria, Nigeria.

S. Gadimoh, National Research Institute for Chemical Technology, P.M.B. 1052, Zaria Nigeria.

K. O. Nwanya, National Research Institute for Chemical Technology, P.M.B. 1052, Zaria Nigeria.

O. J. Okunola, National Research Institute for Chemical Technology, P.M.B. 1052, Zaria Nigeria. 
collected in the Southern part of Nigeria. These seeds are collected and kernels are separated by breaking the capsules. These kernels are crushed in the crushers and the oil is filtered. At present rubber seed oil does not find any major application and hence even the natura production of seeds itself remain underutilized. Infact in Nigeria RSO is yet to receive any serious attempt at its production and utilization. The objective of this discourse therefore is to characterise the rubber seed oil to expose the potential areas unrefined RSO could be used especially in the production of biodiesel at low cost after reducing the FFA and its comparism with fossil diesel and other biodiesel produced from non-edible sources.

However, a major barrier in the commercialization of biodiesel production from vegetable oils is its high manufacturing cost which is due to the higher cost of virgin vegetable oil. Their use in direct injection diesel engines is restricted by some unfavorable physical properties particularly their viscosity. The high viscosity is due to large molecular mass and chemical structure of vegetable oils, this in turn leads to atomization, incomplete combustion and carbon deposition on the injector and valve seats resulting in serious engine fouling (Recep et al., 2004). Due to high viscosity in long term operation, vegetable oils normally induce the development of gumming, the formation of injector deposits, ring sticking, as well as in compatibility (Ramadhas et al., 2004). This necessitated the reduction in viscosity of the vegetable oils for use in compression ignition engines. The commonly employed methods to reduce the viscosity of the vegetable oils are blending with diesel emulsification, pyrolysis, cracking and transesterification (Ramadhas et al., 2004). Among these, transesterification of vegetable oils appears to be more suitable because of the by-product (glycerol) which has high commercial value. Therefore, the purpose of this present study is to reduce the FFA of rubber seed oil to less than 1 by esterification and compare study the properties of the oils with other non-edible oils.

\section{MATERIALS AND METHODS}

In characterizing the rubber seed, the major parameters measured were density, viscosity, saponification number of the oil, flash point, calorific value and acid value. The equipment and materials that were used in this investigation included mechanical extractor (oil press machine), Pensky-Martins Flash Point Equipment, B. Mehler-cook Bomb Calorimeter, Viscometer, thermometer and glassware. All the methyl ester of rubber seed oil was done at Nigerian National Petroleum Corporation (NNPC) Kaduna.

Transesterification (alcoholysis) is the chemical reaction between triglycerides in the vegetable oils and alcohol in the presence of catalyst to produce monoesters. The properties of these esters are comparable to that of diesel. The overall transesterification reaction can be represented by the following reaction scheme.

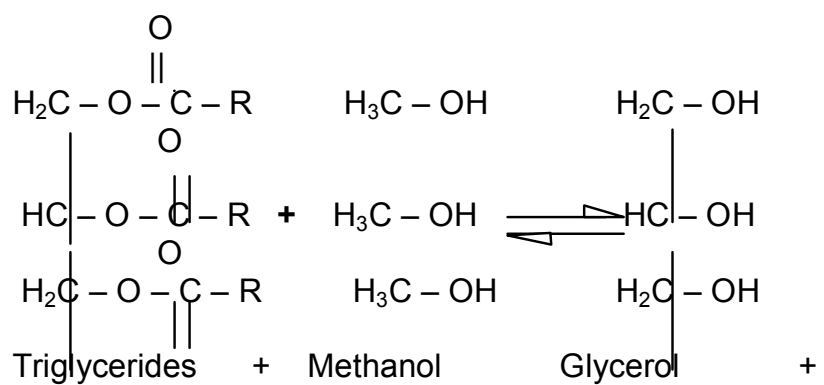

The process consists of 2 steps namely acid esterification using polytoluene sulphonilic acid (PTSA) and alkaline esterifiation.

Acid esterification: This first step reduces the FFA value of crude rubber seed oil to about $1 \%$ using acid catalyst.

Alkali transesterifiation: After removing the impurities of the product of first step, it is transesterified to monoesters of fatty acid usigng alkaline catalyst.

\section{Acid esterification}

Titration of the oil to be transesterified is carried out to ascertain the number of acid value, when the acid value is determine and FFA content calculated, transesterification is then carried out according to Ramadhas et al. (2004).

\section{Alkali transesterification set up}

Similar to acid transesterification, alkali transesterification was done according to Ramadhas et al. (2004). The RSO oil is heated to about $60^{\circ} \mathrm{C}$ and the<smiles>[R]COC(=O)OC([R])=C([R])OC</smiles>

mixture is stirred at the speed of $360 \mathrm{rpm}$. The temperature range of $50-60^{\circ} \mathrm{C}$ is maintained during this experiment.

\section{RESULTS AND DISCUSSION}

The fatty acid composition and the important properties of rubber seed oil in comparison with other oils is given in Table 1. It consists of $18.9 \%$ saturation comprising of palmitic and stearic acids and $80.5 \%$ unstauration comprising mainly of oleic, Linoleic and linolenic acids. Saturation fatty acid methyl esters increase the cloud point, cetane number and improve stability whereas more poly unsaturates reduce the cloud point and cetane number and stability. The type and percentage of fatty acids contained in vegetable oil depends on the plant species and on the growth conditions of the plant. Though vegetable oils are of very low volatility in nature, it quickly produces volatile combustible compounds upon heating (Canakei and VanGerpan, 2001). 
Table 1: Properties of Rubber seed oil in Comparison with the other vegetable oils

\begin{tabular}{|c|c|c|c|c|}
\hline Property & $\begin{array}{l}\text { Crude Rubber } \\
\text { Seed Oil }\end{array}$ & $\begin{array}{l}\text { Refined Rubber } \\
\text { Seed Oil }\end{array}$ & Rape Seed Oil* & Soy bean Oil* \\
\hline $\begin{array}{l}\text { Fatty acid comp (\%) } \\
\text { (i) Palmitic acid } \mathrm{C}_{16.0}\end{array}$ & 10.2 & 9.8 & 3.49 & 11.75 \\
\hline (ii) Stearic acid $\mathrm{C}_{18.0}$ & 8.7 & 8.2 & 0.85 & 3.15 \\
\hline (iii) Oleic acid $\mathrm{C}_{18.1}$ & 24.6 & 23.9 & 64.4 & 23.26 \\
\hline $\begin{array}{lll}\text { (iv) Linoleic acid } \\
\mathrm{C}_{18: 2}\end{array}$ & 39.6 & 38.7 & 22.3 & 55.53 \\
\hline $\begin{array}{l}\text { (v) Linolenic acid } \\
\mathrm{C}_{18.3}\end{array}$ & 16.3 & 15.95 & 8.23 & 6.31 \\
\hline Specific gravity & 0.920 & 0.918 & & \\
\hline $\begin{array}{l}\text { Viscosity }\left(\mathrm{mm}^{2} / \mathrm{s}\right) @ \\
40^{\circ} \mathrm{C}\end{array}$ & 66.2 & 65.5 & 39.5 & 65 \\
\hline Flash point $\left({ }^{\circ} \mathrm{C}\right)$ & 198 & 194 & 280 & 230 \\
\hline Calorific value MJ/kg & 39.5 & 37.5 & 37.6 & 39.6 \\
\hline Acid value & 7 & 1 & 1.14 & 0.2 \\
\hline
\end{tabular}

- Ramadhas et al. (2005).

The free fatty acid (FFA) content of unrefined rubber seed oil was about $14 \%$. The yield of esterification process decreases considerably if FFA value is greater than $2 \%$. Canakci and Van Gerpan (2001) and Recep et al. (2001) found that tranesterification would not occur if FFA content in the oil were about $3 \%$. It has been found that the alkaline catalyzed transesterification process is not suitable to produce esters from unrefined oils. Inorder to reduce the acid value (i.e reducing FFA), the oil is to be refined. Refining of vegetable oils increases the overall production cost of the biodiesel. Acid esterification is a typical method of producing biodiesel from high FFA oil (Agarwal and Das, 2001). But it requires more methanol and is time consuming also. Developement of any method to produce the biodiesel from high FFA oils is significant. Hence, efforts are made to esterify a typical high FFA type of oil in this study.

The fuel properties of rubber seed oil methyl esters in comparison with that of other esters is shown in Table 2 (Nwankwo et al., 1985; Aigbodion, 1991; Canakei and VanGerpan, 2001; Ramadhas et al., 2004; lyayi et al., 2007). The testing procedures adopted for the fuel properties are also given in Table 2. Most of the fuel properties of rubber seed oil methylester are quite comparable to those of other esters and diesel. The chromatographic analysis supports that the biodiesel contains large amount of $\mathrm{C}_{18}$. The $\mathrm{C}, \mathrm{H}, \mathrm{O}$ composition of rubber seed oil methyl ester are 76.85, 11.82 and $11.32 \%$ respectively.

The present result obtained show that, the transesterification process improved the fuel properties of the oil with respect to specific gravity, viscosity, flash point and acid value. The comparison of these properties with diesel shows that the methyl ester has a relatively close fuel propety values to that of diesel (than that of oil). The viscosity of bioldiesel is close to that of diesel but high viscosity of Rubber seed methyl ester affect the combustion performance. 
Table 2: Properties of methyl esters of rubber seed oil in comparison with other esters.

\begin{tabular}{|c|c|c|c|c|c|c|}
\hline Property & $\begin{array}{l}\text { Testing } \\
\text { procedure }\end{array}$ & $\begin{array}{l}\text { Biodiesel } \\
\text { Standard } \\
\text { ASTM } \\
6751-02\end{array}$ & $\begin{array}{l}\text { ASTM D- } \\
975 \text { (Diesel) }\end{array}$ & $\begin{array}{l}\text { Rubber } \\
\text { Seed Oil } \\
\text { Methylester }\end{array}$ & $\begin{array}{l}{ }^{*} \text { Rape seed } \\
\text { oil methyl } \\
\text { ester }\end{array}$ & $\begin{array}{l}{ }^{*} \text { Soyaben } \\
\text { oil } \\
\text { methylester }\end{array}$ \\
\hline Appearance & Visual & NA & NA & $\begin{array}{l}\text { Free flowing } \\
\text { Brown liquid }\end{array}$ & NA & NA \\
\hline $\begin{array}{l}\text { Specific } \\
\text { gravity @ } \\
40^{\circ} \mathrm{C}\end{array}$ & $\begin{array}{ll}\text { ASTM } & \text { D- } \\
1298 & \end{array}$ & $0.86-0.90$ & 0.835 & 0.886 & 0.882 & 0.885 \\
\hline AP1 gravity & $\begin{array}{l}\text { ASTM D- } \\
287\end{array}$ & NA & NA & 28.1 & NA & NA \\
\hline $\begin{array}{l}\text { Flash pooint } \\
(\mathrm{oC})\end{array}$ & $\begin{array}{l}\text { ASTM D- } \\
92 / 93\end{array}$ & Mn 130 & $60-82$ & 152 & 170 & 69 \\
\hline $\begin{array}{l}\text { Cloud point } \\
\left({ }^{\circ} \mathrm{C}\right)\end{array}$ & $\begin{array}{l}\text { ASTM D- } \\
2500\end{array}$ & -3 to 12 & -5 to 5 & 9 & -4 & -2 \\
\hline Pour point & $\begin{array}{ll}\text { ASTM } & \text { D- } \\
5853 & \\
\end{array}$ & -15 to 10 & -35 to 15 & 3 & -22 & -6 \\
\hline $\begin{array}{l}\text { Calorific } \\
\text { value, } \\
\mathrm{MJ} / \mathrm{kg} \\
\end{array}$ & $\begin{array}{ll}\text { ASTM } & \text { D- } \\
240 & \end{array}$ & NA & $42-46$ & 36.5 & 37.0 & 39.7 \\
\hline $\begin{array}{l}\text { Kinematic } \\
\text { viscosity @ } \\
40^{\circ} \mathrm{C}\end{array}$ & $\begin{array}{ll}\text { ASTM } & \text { D- } \\
445 & \end{array}$ & $1.9-6.0$ & $1.3-4.1$ & 6.0 & 4.9 & 4 \\
\hline $\begin{array}{l}\text { Sulphur } \\
\text { Content }\end{array}$ & & 0 & 0.05 max & $\begin{array}{c}1.3 \\
0.04 \\
\end{array}$ & $\begin{array}{l}\text { NA } \\
\text { NA }\end{array}$ & $\begin{array}{l}\text { NA } \\
\text { NA }\end{array}$ \\
\hline $\begin{array}{l}\text { Aniline point } \\
\left({ }^{\circ} \mathrm{C}\right)\end{array}$ & $\begin{array}{ll}\text { ASTM D- } \\
611\end{array}$ & NA & NA & 26.8 & NA & NA \\
\hline $\begin{array}{l}\text { Acid value } \\
(\mathrm{mg} \mathrm{KOH} / \mathrm{g})\end{array}$ & & NA & NA & 0.118 & NA & NA \\
\hline $\begin{array}{l}\text { Ester } \\
\text { content (\%) }\end{array}$ & & - & - & 94 & 90 & 95 \\
\hline
\end{tabular}

$\mathrm{NA}=$ Not available

* Ramadhas et al. (2005). 
Hence, no hardware modificiations are require for handling this fuel (biodiesel) in the existing engine. The calorific values of methyl esters are lower than that of diesel because of their oxygen content.The calorific value of the biodiesel is an indication that the fuel will burn completely with the release of high energy which could be utilized to power diesel engine just like petroleum diesel. The presence of oxygen in the biodiesel helps for complete combustion of fuel in the engine. The flash point is the lowest temperature at which the vapour produced by the biodiesel would ignite on introduction of a test flame indicates a safe storage of biodiesel. The flash point of rubber seed oil is lowered by transesterification but it is still higher than that of diesel. A smalll percentage addition of biodiesel with diesel increases the flash point of diesel. Hence it is safer to store biodiesel - diesel blends as scompared to diesel alone. The ester content of $94 \%$ showed the high degree of conversion of rubber seed oil into methyl ester. The properties of biodiesel are compared with ASTM biodiesel standards. The tested properties of methyl esters of rubber seed oil are found to be in reasonable agreement with ASTM 6751.

\section{CONCLUSIONS}

The production of fuel-quality biodeisel from low cost, high FFA feedstock is investigated in the present study. It is found that the feedstock with very high FFAs could not be transesterified with commercially available alkaline catalyst transesterification process. The reason is alkaline catalysts react with the FFAs to form soap that prevents the sepearation of the glycerine and ester. A two-step transesterification process is developed to convert the high FFA oils to its esters. The first step (acid catalysed transesterification) reduces the FFA content of the oil to $1 \%$ and the alkaline catalyst transesterification process converts the products of the first step to its mono-esters and glycerol. The properties of rubber seed oil analysed showed that biodiesel from refined rubber seed oil are comparable with ASTM biodiesel standards and is quiet suitable as an alternative to diesel.

\section{REFERENCES}

Agarwal, A. K. and Das, L. M., 2001. Biodiesel development and characterization for use in compression ignition engines. Trans Am Soc Mech. Eng., 123: 440-7.

Aigbodion, A. I., 1991. Ind. J. Nat. Rubb Res. 4(2):114117.

Canakei, M. and Van Gerpan, J., 1999. Biodiesel production via acid catalyst. Trans Am Soc Agric Eng., 42(5): 1203-10.

Canakei, M. and Van Gerpan, J., 2001. Biodiesel production from oils and fats with high free fatty acids. Trans ASAE, 44:1429-36.

Erhan, S. Z., Sharma, B. K., and Perez, J. M., 2006. Ind. Crop products, 24 (30): 292-299.

Iyayi, A.F., Akpaka, P.O., Ukpeoyibo, U., Balogun, F.E., and Momodu, I.O., 2007. Rubber seed oil: an oil with great potentials. ChemTech Journal, 3: $507-516$.

John W. G, Mark A. E., 1996. Physical properties of low molecular weight triglycerides for the development of biodiesel fuel models. Bioresour Technol., 56:55-60.

Nwankwo B. A., Aigbekan E. O. and Sagay, G.A., 1985. In: Enabor, E.E.; editor. Proc. Nat. Cont. Industrial utilization of NR, Seed and wood 7887.

Pilar D. M., Evaristo B., Franscisco J. L. and Martin M., 2004.Optimization of alkali-catalyzed transesterification of brassica carinata oil for biodiesel production. Energy Fuels, 18:77-83.

Ramadhas A. S., Jayaraj S. and Muraleedharan C., 2004. Use of vegetable oils as I.C. engine fuels-a review. Renewab Energy, 29:727-42.

Ramadhas A. S., Muraleedharan C. and Jayaraj, S., 2005. Performance and emission evaluation of a diesel engine fueled with methyl esters of rubber seed oil. Renew Energy, 30:1789-800.

Recep A, Selim C, Huseyin S. Y., 2001. The potential of using vegetable oils as fuels for diesel engines. Energy Conv. Mgmt, 42:529-38. 
